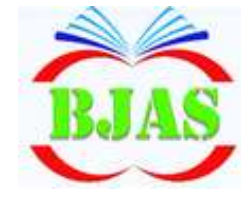

ISSN $1814-5868$
Available online at http://bjas.bajas.edu.iq

https://doi.org/10.37077/25200860.2021.34.2.11

College of Agriculture, University of Basrah

\section{Basrah Journal}

of Agricultural

Sciences

E-ISSN: 2520-0860

\title{
First Record of Two Parasitic Helminths from Cobia Rachycentron canadum (L.) (Carangiformes, Rachycentridae) from Iraqi Marine Waters
}

\author{
Jawad A. Mizher \& Atheer H. Ali*
}

Department of Fisheries and Marine Resources, College of Agriculture, University of Basrah, Iraq

*Corresponding author: atheeralibu@gmail.com Received 12 March 2021; Accepted 8 June 2021; Available online 4 November 2021

\begin{abstract}
A total of 14 specimens of Cobia Rachycentron canadum (L.) were caught from Iraqi marine waters during the period from October 2019 till May 2020. Two parasitic helminths (One species each of nematode and acanthocephalan) were isolated from alimentary canal of the cobia. These are the adults of Iheringascaris inquies (Linton, 1901) Deardorff \& Overstreet, 1980 and Serrasentis sagittifer Linton, 1889. The record of these worms, from this fish, is considered as the first record in Iraq. Adequate description of both I. inquies and adult S. sagittifer from cobia for the first time in the Arabian Gulf is given.
\end{abstract}

Keywords: Marine fish, Nematoda, Iheringascaris inquies, Acanthocephala, Serrasentis sagittifer, Iraq.

\section{Introduction}

Cobia, a world-wide species, is distributed in most seas and oceans in open waters and rarely enters the estuaries (Froese \& Pauly, 2021), with $200 \mathrm{~cm}$ in maximum length; it is a predator on crustaceans and fishes (Carpenter et al., 1997), This fish was also recorded in Iraq (Ali et al., 2018). Cobia is one of the important commercial fishes due to its very good food coefficient ratio (FCR) and high growth rates and currently used in mariculture in 23 countries, mostly in south eastern Asia (Liao et al., 2004; Nhu et al., 2011). Al-Mukhtar (2011) recommended using the cobia in mariculture in Iraq.

For long time, Iheringascaris Pereira, 1935 is still monotypic species: I. inquies (Linton, 1901), beside other seven genera including
Hysterothylacium which is placed in family Ascarididae, subfamily Raphidascaridinae, which have excretory pore situated close to nerve ring in addition to the unique shape of ventriculus (Gibbons, 2010). However, Gibbons (2010) and Moravec et al. (2012a) placed Iheringascaris within the family Anisakidae, considering the above taxonomical characters as not enough for creating Raphiascaridae at the family level. Malhotra $e t$ al. (2012) and WoRMS (2021) put the Iheringascaris within Raphidascaridae.

Serrasentis Van Cleave, 1923 belongs to Rhadinorhynchidae beside 22 other genera (Amin, 2013). The genus Serrasentis has five nominal species (Barton et al., 2018; WoRMS, 2021), instead of 22 species listed historically 
Mizher \& Ali / Basrah J. Agric. Sci., 34(2): 133-146, 2021

(Gibson \& Wayland, 2021). At Pakistani waters, Bilqees (1971) described S. longiformis Bilqees, 1971 (now a taxon inquirendum) from Arius serratus (= Netuma thalassina). Bilqees (1972a) described S. sciaenus (now uncertain) from Sciaenus dussumieri (=Johnius dussumieri) and S. mujibi (=S. nadakali George \& Nadakal, 1978) and from $R$. canadus $(=R$. canadum); while Bilqees (1972b) described Serrasentis giganticus Bilqees, 1972 (=S. sagittifer) from $R$. canadum. Bilqees \& Khan (2005) described S. manazo Bilqees \& Khan, 2005 from the shark Myrmilo manazo (=Mustelus manazo) from Pakistan. Khatoon \& Bilqees (2007) described cystacanth of S. niger Khatoon \& Bilqees, 2007 (now a taxon inquirendum) from Parastromateus niger.

At Kuwaiti waters, Amin et al. (1984) isolated $S$. sagittifer cystacanths from five marine fishes, viz: Lutjanus coccineus, $L$. fulviflamma, Nemipteris japonicas, N. tolu and Otolithes ruber.

In Iraq, three species belonging to Rhadinorhynchidae were recorded. Micracanthorhynchina kuwaitensis (misspelled as Micracanthorhynchus) Amin and Sey, 1996, Slendrorhynchus breviclaviproboscis Amin \& Sey, 1996 reported from Hemiramphus marginatus off Khor Abdullah by Bannai (2005) and S. sagittifer as a larval stage recorded from Platax teira and Acanthopagrus arabicus in addition to three unidentified larval stages of Serrasentis from Brachirus orientalis, Johnius belangeri and Otolithes ruber (Mhaisen et al., 2018). Bannai (2018) added Upeneus sulphureus as a new host in Iraq for Serrasentis sp., and he examined the food items of the host which included amphipods and other crustaceans that may role as intermediate hosts for this parasite.

Due to the absence of any parasitological study on $R$. canadum in Iraq, the current study aims to give the information on some of the parasite fauna of this commercial fish.

\section{Materials \& Methods}

A total of 14 specimens of Rachycentron canadum were examined for endoparasites during May 2019 till October 2020 from marine waters of Iraq

The isolated nematodes were washed and fixed in hot $4 \%$ formalin. Two days later, they were transferred to $70 \%$ ethanol for preservation. Three different solutions (Glycerin: water, Amman's lactophenol and glacial acetic acid) were used for clearing the nematode according to what the structure of the parasite could be seen (Berland, 1984; Moravec, 1994), In addition, the enface view of head of nematode was mounted with glycerin jelly (Moravec, 1994; Ali, 2008).

The acanthocephalans, after cleaning from the debris, were put overnight in refrigerator for relaxing and protrusion of the proboscis, then, they were put in cold distilled water, fixed and preserved in cold $70 \%$ ethanol (Amin et al., 2018), stained in Mayer-Schuberg's Aceto carmine, cleared in methyl salicylate and mounted in Canada balsam (Palm, 2004). All measurements, unless otherwise indicated, were taken in micrometers. Host taxonomy followed Carpenter et al. (1997) and verified by Van der Laan et al. (2021). 


\section{Results \& Discussions}

Family: Raphidascarididae

Iheringascaris inquies (Linton, 1901)

Site of infection: Stomach and fore intestine.

Prevalence and mean intensity: $28 \%$ and 45 , respectively.

Deposition: Iraqi Natural History Research Center and Museum, SN: INHM-NC2-NC21.

\section{Description (Figs. 1 and 2)}

Whitish, narrow nematode, maximum wide in the middle of the body, highly striated transversely cuticle form serrated appearance (Fig. 1A). The ala is absent, and the presence of longitudinal groove (Fig. 1A). Three lips longer than the wide. Dorsal lip has double papillae, slightly larger than the subventral lips. Each subventral lip has single papilla. Interlabia triangle and well developed, 32-50 in length. Long esophagus with slightly globular ventriculus. Short caecum, narrow ventral appendage and longer than the caecum. The excretory pore slightly posterior to nerve ring (Fig. 1A). Long, equal spicules. Caudal papillae consist of precloacal and postcloacal papillae. Additional row of postcloacal papillae present. Vulva prequatorial, tail conical in both genders and has phasmid in females.

Immature males and females are whitish slender worm with clear striated cuticle. Welldeveloped lips, interlabia in the beginning of growth, some of which exist in the last molting (from $4^{\text {th }}$ larval stage to adult). The immature males have long spicules inside the body with spiral shape, may be not well sclerotized, caudal papillae not developed yet. The reproductive system of the immature females not developed, no eggs. The vulva preequatorial.

\section{Males (10 specimens), immature males in square brackets [two specimens]}

Total length 17.2-28.5 (24.8) [12.8, 18.7] mm and $0.35-0.57(0.48) \quad[0.18,0.22] \mathrm{mm}$ in maximum width, ratio of maximum width to maximum length 1: 44-60 (52) [1: 71, 85], the lips 90-110 [80] in length and 90-163 (140) [110-125] in width. Esophagus 2450-1744 (3284) [2100, 3100] in length and 110$135(123)[110,125]$ in width, comprising 1214 (13.2) [16, 17]\% from total length. Nerve ring and excretory pore 320-450 (409) [275, 300] and 470-700 (572) [210, 400] from anterior extremity, respectively. Ventriculus 110-220 (155) [80, 110] in length and 80-160 (125) $[75,90]$ in width. Caecum 150-420 (275) $[167,200]$ in length and 70-120 (93) $[50,60]$ in width. Appendage 700-1950 (1285) [525, 740] in length and 27-70 (580) $[25,35]$ in maximum width. Ratio of appendage to esophagus 1: 1.52.8 (2.6) [1:4], ratio of caecum to each of esophagus and appendage 1:7-19.6 [1:13, 16] and 1: 3-8 (5.4) [1:3, 4], respectively. The spicules similar and unequal (Fig. 1E), right spicule 3450-6200 (4829) in length and 30-45 (36) in width, left spicule 3650-6000 (4612) in length and 30-45 (35) in width. Ratio of spicules length 14-22 (19) \% of body length. Caudal papillae 22-31 pairs, 14-19 pairs of precloacal and six postcloacal papillae, six pairs of lateral papillae (Fig. 2A), in addition to presence of medioventral preanal papilla. Tail conical and flexed ventrally, 87-120 (103) [90, $100]$ in length. 
Females (10 specimens), immature females in square brackets [Five specimens]

Length of body 18.5-40 (31) [15.8-20.1 (18.9)] $\mathrm{mm}$ and $0.37-0.77$ (0.59) [0.22-0.33 (0.27)] $\mathrm{mm}$ in maximum width. Ratio of the width to body length 1:46-67 (53) [1:53-88 (71)], lips 100-130 (115) [80-100 (90)] in length and 90200 (162) [130-140 (137)] in width. Esophagus 3250-4950 (3963) [240-3170 (2620)] in length and 80-150 (122) [75-100 (89)] in width, about 11-19 (13) [12-17 (14)] \% from body length. Nerve ring and excretory pore 360-480 [320360 (342)] and 450-710 (595) [390-500 (450)] from anterior extremity. Ventriculus 140-250 (175) [85-100 (95)] in length and 120-180 (155) [80-100 (88)] in width. Caecum 170-500 (314) [210-230 (221)] in length and 90-350 (180) [45-60 (54)] in width. Appendage 11002000 (1531) [520-800 (668)] in length and 80125 (100) [30-45 (39)] in width. Ratio of appendage to esophagus 1:1.9-3.4 (2.8) [1: 4-5 (4.3)]. Ratio of caecum to each of esophagus and appendage 1: 9.9-19.1 (14.2) [1:11-14 (12)] and 1: 3-8 (5) [1: 2-4 (3)], respectively. Vulva not elevated (Fig. 1F) from body surface and situated at 5650-14200 (11012) [7000-8150 (7488)] and about 30.5-37.9 (35) [35-44 (41)] $\%$ from anterior extremity. The subglobular eggs (Fig. 1G), 38-50 (46) × 37-43 (41). The conical tail 330-650 (474) [270-300 (294)] in length, with sharp tip and has pair of lateral phasmids in its middle part (Fig. 1H, 2D).

The present worms (I. inquies) have highly striated and serrated cuticle, possessing additional pair of lateral row of caudal papillae in the male, so hence they are in agreement with the genus Iheringascaris Pereira, 1935 according to Gibbons (2010). The description of most of the current specimens is agreeable with the description of I. inquies from the same type host ( $R$. canadum) by Deardorff \& Overstreet (1981) who resurrected the genus Iheringascaris, which was originally placed as a synonym of Thynascaris (=Hysterothylacium) by Hartwich (1974).

The maximum length of females of the present study reached $40 \mathrm{~mm}$ in comparison with $30 \mathrm{~mm}$ and $29.7 \mathrm{~mm}$ by Deardorff \& Overstreet (1981) and Moravec et al. (2012a), respectively. Bruce \& Cannon (1989) recorded I. inquies from cobia at Australian waters, with some variations in the length of females that considered as interspecific differences caused by the variation in the geographical distribution. Based on two specimens of this parasite, Petter \& Sey (1997) reported I. inquies from cobia in the Arabian Gulf at Kuwaiti coasts. Moravec et al. (2012a) added new data on the parasite with the aid of SEM technique from $R$. canadum from Atlantic Ocean, off Carolina (United States), by absence of the alae and presence of longitudinal groove and the number of caudal papillae (33 pairs). Interestingly, the presence of the groove instead of alae was confirmed here by light microscope study too as well as number of caudal papillae of the present study (22-31) is somewhat close to 33. Malhotra et al. (2012) described the second species in the genus (I. goai) from intestine of Sillago sihama and spotted sea catfish Arius maculatus from eastern coast of India; Moravec et al. (2012a) considered the latter species as to need more investigation on its validity. Based on the nature of cuticle as highly striated, Moravec et al. (2012b) transferred two species of Hysterothylacium (H. neocornuta Rao \& Shyamasundari, 1992 and $H$. japonica Rao \& Shyamasundari, 1992) 
Mizher \& Ali / Basrah J. Agric. Sci., 34(2): 133-146, 2021



Fig. (1): Iheringascaris inquies adult. A: anterior end, B: lips, enface view, C: anterior part, D: posterior end of male, E: tip of spicule, F: vagina, G: eggs, H: posterior end of female. Abbreviations: ep: excretory pore, ic: intestinal caecum, in: interlabia, l: lip, nr: nerve ring, oe: oesophagus, v, ventriculus, va, ventral appendage. Scale bar $A=200 \mu \mathrm{m}, \mathrm{B}, \mathrm{E}, \mathrm{G}=100 \mu \mathrm{m}, \mathrm{H}, \mathrm{F}=$ $500 \mu \mathrm{m}, \mathrm{D}=1000 \mu \mathrm{m}$. 
Mizher \& Ali / Basrah J. Agric. Sci., 34(2): 133-146, 2021

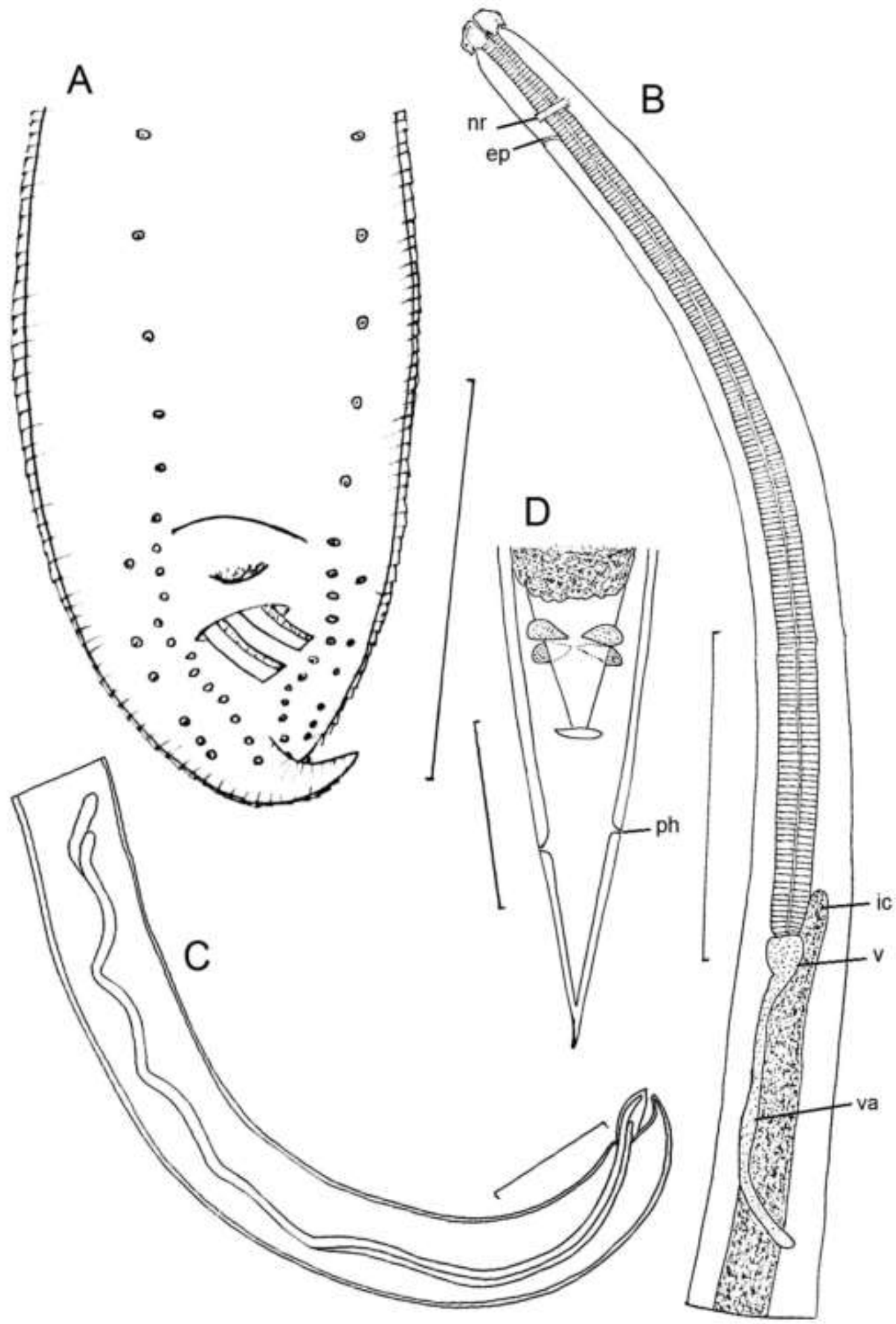

Fig. (2): Iheringascaris inquies. A- posterior part of male demonstrating the distribution of caudal papillae, B- anterior part of juvenile male, $C$ - posterior part of juvenile male, D- tail of juvenile female. Abbreviations: ep: excretory pore, ic: intestinal caecum, nr: nerve ring, ph: phasmid, v: ventriculus, va: ventral appendage. Scale bars, $A, C-D=200 \mu \mathrm{m}, B=1000 \mu \mathrm{m}$. 


\section{Mizher \& Ali / Basrah J. Agric. Sci., 34(2): 133-146, 2021}

from Indian waters to Iheringascaris and became I. neocornuta (Rao \& Shyamasundari, 1992) and I. japonica (Rao \& Shyamasundari, 1992), respectively.

The morphology of adult and immature of $I$. inquies of the present study, indicated that the position of vulva along body length is being similar between them. The spicules are shorter in the immature males than in the adult, the ratio of esophagus to length of body is somewhat longer in the immature than in the adult. The record of adult $I$. inquies is considered as the first in Iraq.

\section{Family: Isthmosacanthidae}

\section{Serrasentis sagittifer (Linton, 1889)}

Site of infection: Fore intestine, close to caeca.

Prevalence and mean intensity: $71 \%$ and 14.8 , respectively.

Deposition: Iraqi Natural History Research Center and Museum, SN: INHM-AC1-AC25.

\section{Description (Figs. 3 and 4)}

Whitish large cylindrical worms, females larger than males. The posterior end of body wider than anterior end. The big worms possess transverse pseudo segmentation anteriorly. Proboscis cylindrical or claviform, flexed ventrally, armed with hooks longitudinally, the ventral rows more robust than dorsal rows (Figs. 3A, B), hooks 3 and 4 the larger ones. Neck short and conical in shape. Proboscis receptacle has double membrane, ganglion in the middle of proboscis receptacle. Lemnisci long and consist three times than proboscis receptacle. The neck aspinous, the anterior trunk surrounding with number of hooks (Figs. 3A-C), that conforms irregular rings, 7-9 in number with $16-20$ hooks. The ventral combs (number of small spines formed hemi circle) extending to middle of the body, the number of them larger in the females than in the males. The first group of combs close to each other compared with the posterior ones.

\section{Males (12 specimens, fig. 3A)}

Trunk length 20-90 (50.160) $\mathrm{mm}$, anterior end 0.5-0.82 (0.7) $\mathrm{mm}$ in width, posterior end 0.651.25 (0.96) $\mathrm{mm}$ in width. Proboscis 700-1050 (898) in length and 250-400 (342) in width, armed with longitudinal hooks, 22-24 (22.8) in number, each row possessed 16-19 (17.4) hooks equal in length, the mean length of four specimens from tip to base of proboscis 30-75 (50), 30-75 (53), 33-80 (57), 38-57 (62), 45-73 (65), 50-70 (65), 50-68 (63), 50-67 (62), 48-63 (56), 42-63 (55), 38-60 (52), 33-58 (48), 33-55 (43), 28-55 (37) and 25-50 (34). The neck 300400 (365) in length and 260-430 (350) in width in the base. Proboscis receptacle 1280-2400 (1765) in length and 170-340 (295) in width. Lemnisci 2300-7700 (5423) in length and 90150 (120) in width. The spines in the anterior part of body 7-9 (8) irregular rings, the length of larger hook 50-85 (71). Number of ventral combs 19-24 (22), length of larger spine in the comb 70-110 (92). The testes tandem and separated with level of 1-2 combs. Anterior and posterior testes 650-1500 (1095) and 730-1800 (1183) in length and 180-480 (311) and 170380 (311) in width, respectively. Cement glands four, very long, 9150-28060 (20190) in length and 90-170 (109) in width. Saefftigen's pouch 1400-2250 (1871) in length, copulatory organ (Fig. 3A) 550-1200 (890) in length and 450-1000 (810) in width.

\section{Females (12 specimens, fig. 3B)}

Trunk length 19.25-100 mm in length and 0.43$0.98(0.77) \mathrm{mm}$ in width. Width of posterior 
end 0.9-2.44 (1.5) $\mathrm{mm}$, proboscis length 8001050 (931) and 280-450 (397) in width, armed with 22-24 (23) longitudinal hooks, each row contains 16-20 (19) hooks, measurement of hooks, 30-55 (46), 33-70 (54), 43-80 (64), 5580 (69), 50-90 (73), 54-90 (71), 40-80 (63), 4080 (63), 38-75 (57), 38-75 (57), 40-73 (55), 3870 (52), 35-70 (50), 35-65 (49), 30-65 (46) and 28-60 (43). The neck 220-310 (277) in length and 260-330 (287) in width. Proboscis receptacle 1600-3172 (2002) and maximum width 190-537 (331). Lemnisci 2450-7000 (5398) and maximum width 130-150 (145). Spine rings in the anterior of body 7-8 in number, the biggest spine 48-115 (82) in length. Spine combs 21-32 (26) in number, biggest spine 70-120 (95) in length. Female reproductive system short, 2400-3200 (2900). Eggs spindle shaped, 50-108 (75) × 12-25 (19) .

\section{Serrasentis sagittifer cystacanths}

Site of infection: Mesenteries, intestine.

\section{Description (Five specimens, fig. 4F)}

Small whitish worms, 3.7-11.45 (6.69) $\mathrm{mm}$ in trunk length, 0.3-0.6 (0.44) $\mathrm{mm}$ in maximum width, flexed ventrally from both ends $(n=4)$. Posterior extremity 250-450 (345) wider than anterior end. Proboscis 800-1000 (930) in length and 250-360 (320) in width. Proboscis receptacle 900-1600 (1375) in length and 200300 (253) in width. Lemnisci long and reach to middle of body, 2350-4850 (3025) in length and 70-120 (88) in width. Proboscis hooks armature, anterior trunk spine 8-9 rows, longest spine 40-80 (55), ventral spine combs like in the adult, 19-26 (23) in number, longest spine 50-100 (64). The early males have two oval testes in level of combs 10-14. Cement glands and female reproductive system not distinguishable.
The current worms ( $S$. sagittifer) possess cylindrical proboscis and double membrane in proboscis receptacle. Anterior trunk armed with hooks and surrounded with tegument, four long cement glands taxonomically agree with Rhadinorhynchidae, and the specimens have ventral combs of hooks fit with Serrasentis Van Cleave, 1923 (Amin, 2013; Smales, 2015). The taxonomic position of Serrasentis within higher taxa passed controversially changes in recent years. Verweyen et al. (2011), Amin (2013), Smales (2015) and Barton et al. (2018) placed it within Rhadinorhynchidae, order Echinorhynchida. Huston et al. (2020), based on molecular studies on number of marine acanthocephalans transferred Serrasentis with two other genera to Isthomosacanthidae, order Polymorphida.

The characters of this acanthocephalan from cobia could be identified as $S$. sagittifer (Linton, 1889), which is a wide distribution species. It was reported from fishes, mostly as cystacanths, from various regions e.g. Brazil (Luque et al., 1995), India (Bhattachary, 2007), Australia (Smales, 2014), Egypt (Mohamadain \& Adel, 2015) and Arabian Gulf and Gulf of Oman (Amin et al., 1984; Kardousha, 2005; Hosseini et al., 2013; Tavakol et al., 2015). Amin (2013) listed just 14 valid species of Serrasentis, while Barton et al. (2018) discussed the validity of 14 species of Serrasentis and reduced species to five valid species. S. sagittifer shares with S. lamelliger and $S$. nadakali by possessing more than 15 ventral combs. However, $S$. sagittifer is distinguished by 22-24 rows in proboscis armature with 14-18 hooks per row and long cement glands (13.3-45.0 mm) in comparison with 24-28 rows of 20-26 hooks per row; short cement glands $(3.3 \mathrm{~mm})$ in S. nadakali; 


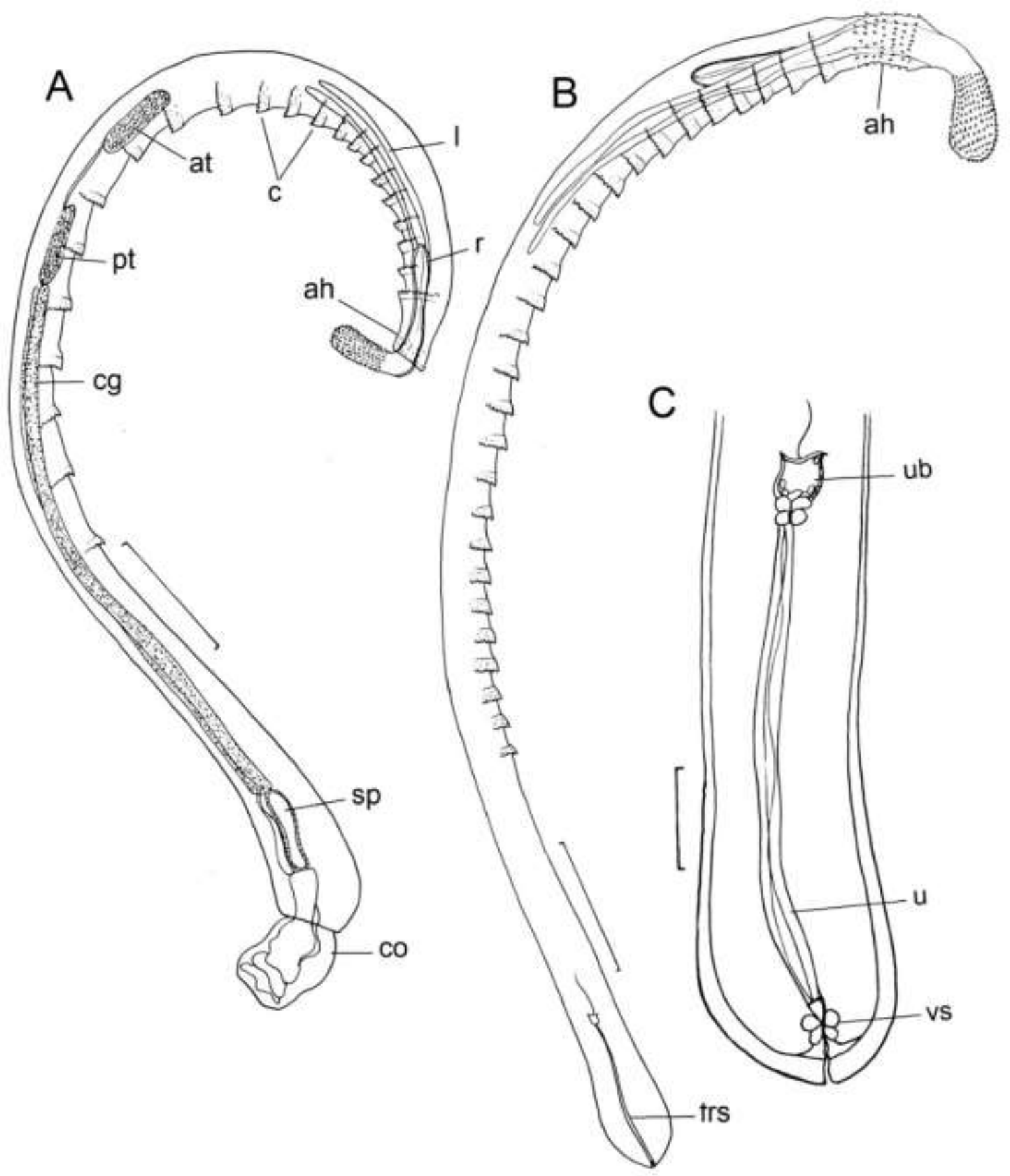

Fig. (3): Serrasentis sagittifer, A- adult male, 2- mature female (no eggs), C- posterior end of female with reproductive system. Abbreviations: ah: anterior hooks, at: anterior testis, c: combs, cg, cement gland, co: copulatory organ, frs: female reproductive system, l: lemnisci, pt: posterior testis, r: receptacle, sp: Saefftigen's pouch, u: uterus, ub: uterus bell, vs: vaginal sphincter. Scale bars: $\mathrm{A}, \mathrm{B}=\mathbf{2 0 0} \mu \mathrm{m}, \mathrm{C}=\mathbf{3 0 0} \mu \mathrm{m}$. 
Mizher \& Ali / Basrah J. Agric. Sci., 34(2): 133-146, 2021



Fig. (4): Serrasentis sagittifer, A: ventral comb row, B- proboscis dorsal hook row, C- anterior hook, D- hook comb from female worm, E- egg, F- cystacanth. Abbreviations: ah: anterior hooks. Scale bars: $A, B=200 \mu \mathrm{m}, \mathrm{C}=60 \mu \mathrm{m}, \mathrm{D}=500 \mu \mathrm{m}, \mathrm{E}=100 \mu \mathrm{m}, \mathrm{F}=300 \mu \mathrm{m}$. 
Mizher \& Ali / Basrah J. Agric. Sci., 34(2): 133-146, 2021

Proboscis armature has 24-31 longitudinal rows of three hooks or six transverse rows (1216 hooks); definitive host is Naucrates doctor (Carangidae) in S. lamelligeter (Barton et al., 2018). S. manazo has three small spines located dorsally on the posterior trunk, while $S$. indicus possessing proboscis armature of 18-20 rows, 10-12 hooks per row and 5-15 ventral combs.

The present report is considered as the first for adult worm of $S$. sagittifer from $R$. canadum in Iraq and Arabian Gulf and hence, this fish is considered as a new third host in Iraq for the parasite. This acanthocephalan was previously reported from Iraq as cystacanths from Acanthopagrus arabicus (reported as Acanthopagrus latus) and then from Platax teira (Mhaisen et al., 2018).

\section{Conclusions}

The present investigation is the first parasitological study on cobia, $R$. canadum in Iraq, It demonstrated the record of adults of two parasitic worms which have high specificity to cobia, the type and the only host for the nematode $I$. inquies and for the adult $S$. sagittifer in the World.

\section{Conflict of interest}

The authors declared that they have no conflict of interest.

\section{Ethical approval}

All applicable national and international guidelines for the care and use of animals were followed.

\section{Orchid}

A. H. Ali: https://orcid.org/0000-0002-2541968X

\section{Acknowledgements}

Sincere thanks are due to Dr. Frantisek Moravec of Institute of Parasitology, Biology Centre of the Czech Academy of Sciences, Czech Republic for identifying the immature nematodes, and Mr. Foad M. Asi from the General Union of Agricultural Societies for his assistance in getting the fish sample from Iraqi fishermen and for the Department of Fisheries and Marine Resources for supporting the work.

\section{References}

Ali, A. H. (2008). Taxonomy of helminth parasites in some marine and freshwater fishes and the relation of some of it's with their final hosts in southern of Iraq. Ph. D. Thesis, College of Agriculture, University of Basrah, 336pp. (In Arabic).

Ali, A. H., Adday, T. K., \& Khamees, N. R. (2018). Catalogue of marine fishes of Iraq. Biological and Applied Environmental Research, 2, 298-368. http://www.vliz.be/en/catalogue?module=ref\&refid= 301431

Al-Mukhtar, M. A. (2011). Rachycentron canadum (Linnaeus, 1766) Rachycentridae in marine aquaculture. Iraqi Journal of Aquaculture 8, 1-14.

Amin, O. M. (2013). Classification of the Acanthocephala. Folia Parasitologica, 60, 273-305. https://doi.org/10.14411/fp.2013.031

Amin, O. M., Heckmann, R. A., \& Ali, A. H. (2018). The finding of Pacific transvenid acanthocephalan in the Arabian Gulf, with the description of Paratrajectura longcementglandatus n. gen., n. sp. from perciform fishes and emendation of Transvenidae. Journal of Parasitology, $\quad 104, \quad 39-\quad 50$. https://doi.org/doi:10.1645/17-84

Amin, O. M., Nahhas, F. M.; Al-Yamani, F., \& Abu Hakima, R. (1984). On three acanthocephalan species from some Arabian Gulf fishes off the coast of Kuwait. Journal of Parasitology, 70, 168-170. https://doi.org/10.2307/3281951

Bannai, M. A. A. (2005). Description of two newly recorded Acanthocephala parasitizing halfbeaked fish Hemiramphus marginatus (Forsskål, 1774) in 


\section{Mizher \& Ali / Basrah J. Agric. Sci., 34(2): 133-146, 2021}

Khor Abdullah, Arabian Gulf, Iraq. Basrah Journal Veterinary Research, 4, 67-71.

Bannai, M. A. A. (2018). Serrasentis sp. acanthocephalans parasite of some Iraqi marine water fishes with observation of the pathology, feeding habits and infection of Upeneus sulphureus fishes. Iraqi Journal of Science, 59, 2173-2178. http://scbaghdad.edu.iq/

eijs/index.php/eijs/article/view/559

Barton, D. P., Smales, L., \& Morgan, J. A. T. (2018). A redescription of Serrasentis sagittifer (Rhadinorhynchidae: Serrasentinae) from Rachycentron canadum (Rachycentridae) with comments on its biology and its relationship to other species of Serrasentis. The Journal of Parasitology, 104, 117- 132. https://doi.org/10.1645/17-94.

Berland, B. (1984). Basic techniques involved in helminth preservation. Systematic Parasitology, 6, 242-245. https://doi.org/10.1007/BF00012195

Bhattacharya, S. B. (2007). Handbook on Indian Acanthocephala. Zoological Survey of India, Kolkata, 225pp. http://faunaofindia.nic.in/PDFVolumes/hpg/027/inde x.pdf

Bilqees, F. M. (1971). Parasites of the cat fish Arius serratus. I. Acanthocephala. Pakistan Journal of Zoology, 3, 57-65.

Bilqees, F. M. (1972a). Serrasentis giganticus n. sp. (Acanthocephala, Rhadinorhynchidae, Serrasentinae), from fishes of Karachi coast. In: Bilqees, F. M., Saeed, R., Rehana, R., Khatoon, A. \& Kaikabad, S. H. (Editors). Helminth parasites of some vertebrates chiefly from fishes of West Pakistan. Agricultural Research Council, Government of Pakistan, Karachj, Pakistan: 60-65.

Bilqees, F. M. (1972b). Two new species of the genus Serrasentis (Acanthocephala: Rhadinorhynchidae) from some fishes of Karachi coast. Pakistan Journal of Science, 24, 121-124.

Bilqees, F. M., \& Khan, A. (2005). Two new helminth parasites from Pakistan, with redescription of the acanthocephalan Centrorhynchus fasciatum (Westrumb, 1821). Pakistan Journal of Zoology, 37, 257-263. https://www.zsp.com.pk/pdf37/PJZ19704\%20_2_.pdf.
Bruce, N. L., \& Cannon, L. R. G. (1989). Hysterothylacium, Iheringascaris and Maricostula new genus, nematodes (Ascaridoidea) from Australian pelagic marine fishes. Journal of Natural History, 23, 1397-1441. https://doi.org/10.1080/00222938900770771

Carpenter, K. E., Krupp, F., Jones, D. A., \& Zajonz, U. (1997). The living marine resources of Kuwait, Eastern Saudi Arabia, Bahrain, Qatar and the United Arab Emirates. FAO species identification field guide for fishery purposes, FAO, Rome: viii + 293pp. + XVII http://www.fao.org/3/v8729e/v8729e00.htm

Deardorff, T. L., \& Overstreet, R. M. (1981). Review of Hysterothylacium and Iheringascaris (both previously= Thynnascaris $)($ Nematoda: Anisakidae $)$ from the northern Gulf of Mexico. Proceedings. Biological Society of Washington, 93, 1035-1079. https://europepmc.org/article/agr/par83010696

Froese, R., \& Pauly, D. (Editors) (2021). FishBase. World Wide Web electronic publication, http://www.fishbase.org, version 03/2021

Gibbons, L. M. (2010). Keys to the nematode parasites of vertebrates: Supplementary volume. CAB Int., Wallingford, $\quad 416 \mathrm{pp}$. https://books.google.iq/books/about/Keys_to_the_N ematode_Parasites_of_Verteb.html?id=Mv3ErHPO5 bsC\&redir_esc $=y$

Gibson, D., \& Wayland, M. (2021). World List of marine Acanthocephala. Serrasentis Van Cleave, 1923. Accessed through: World Register of Marine Species at:http://marinespecies.org/aphia.php?p=taxdetails\&i $\mathrm{d}=20406$ on $2021-02-27$

Hartwich, G. H. (1974). Keys to genera of the Ascaridoidea. In: Anderson, R. C., Chabaud, A. G., \& Willmott, S. (Eds.). CIH keys to the Nematode parasites of vertebrates, No. 2, Commonwealth Agricultural Bureaux, Farnham Royal, Bucks, England, 15pp.

Hosseini, S. H., Alinezhad, S., Mobedi, I., Halajian, A., Karimi, E., Ahoo, M. B., \& Yasemi, M. (2013). Study on the parasite of Pseudorhombus elevates, Psettodes erumei and Brachirus orientalis from the Persian Gulf, Iran. Iranian Journal of Fisheries 


\section{Mizher \& Ali / Basrah J. Agric. Sci., 34(2): 133-146, 2021}

Sciences, 12, 827-835. http://jifro.ir/article-1-1342en.html

Huston, D. C., Cribb, T. H., \& Smales, L. R. (2020). Molecular characterisation of acanthocephalans from Australian marine teleosts: proposal of a new family, synonymy of another and transfer of taxa between orders. Systematic Parasitology, 97, 1-23. https://doi.org/10.1007/s11230-019-09896-2.

Kardousha, M. M. (2005). Helminth parasite larvae collected from Arabian Gulf fish. 4. Description of four larvae including two metacercariae, one didymozoid and one acanthocephalan from Emirati coasts. Arab Gulf Journal of Scientific Research, 23, 23-27.

Khatoon, S., \& Bilqees, F. M. (2007). Description of new acanthocephalan Serrasentis niger (Rhadinorhynchidae: Serrasentinae) from the fish Stromateus niger of Karachi coast. Proceedings of Parasitology, 44, 69-74.

Liao, I. C., Huang, T.-S., Tsai, W.-S., Hsueh, C.-M., Chang, S.-L., \& Leaňo, E. M. (2004). Cobia culture in Taiwan: current status and problems. Aquaculture, 237,155-165.

https://doi.org/10.1016/j.aquaculture.2004.03.007

Luque, J. L.; Amato J. F. R., \& Takemoto R. M. (1995). Helminth larval stages in Orthopristis ruber and Haemulon steindachneri (Osteichthyes: Haemulidae) from the coast of the State of Rio de Janeiro, Brazil. Revista Brazileira de Biologia, 55, 33-38.

Malhotra, A., Jaiswal, N., Malakar, A. K., Verma, M. S., Singh, H. R., Lakra, W. S., Malhotra, S. K., \& Shamsi, S. (2012). The morphology and genetic characterization of Iheringascaris goai n. $\mathrm{sp}$. (Nematoda: Raphidascarididae) from the intestine of the silver whiting and spotted catfish off the central west coast of India. Journal Helminthology, 86, 353362. https://doi.org/10.1017/S0022149X11000472

Mhaisen, F. T., Ali, A. H., \& Khamees, N. R. (2018). Marine fish parasitology of Iraq: A review and checklists. Biological and Applied Environmental Research, 2, 231-297.

Mohamadain, H. S., \& Adel A. (2015). Light and scanning electron microscopy on Serrasentis sagittifer Linton, 1889. (Acanthocephala): Paleaecanthocephala: Rhadinorhynchidae) infecting the common sea bream in Egypt. Journal of the Egyptian Society of Parasitology, 45, 23-28. https://doi.org/doi:10.12816/0010846

Moravec, F. (1994). Parasitic nematodes of freshwater fishes of Europe. Academia Prague, and Kluwer Academic Publishers, Dordrecht: 473pp. https://www.springer.com/gp/book/9780792321729

Moravec, F., Yost, J., \& de Buron, I. (2012a). New data on the morphology of Iheringascaris inquies (Linton, 1901) (Nematoda: Anisakidae), a specific parasite of the marine fish Rachycentron canadum (Linnaeus), as revealed by SEM. Folia Parasitologica, 59, 315-318. https://doi.org/10.14411/fp.2012.045

Moravec, F.; Taraschewski, H., Appelhoff, D., \& Weyl, O. L. (2012b). A new species of Hysterothylacium (Nematoda: Anisakidae) from the giant mottled eel Anguilla marmorata in South Africa. Helminthologia, $\quad 49, \quad$ 174-180. https://doi.org/10.2478/s11687-012-0035-9

Nhu, V. C., Nguyen, H. Q., Le, T. L., Tran, M. T., Sorgeloos, P., Dierckens, K., Reinertsen, H., Kjørsvik, E., \& Svennevig, N. (2011). Cobia Rachycentron canadum aquaculture in Vietnam: recent developments and prospects. Aquaculture, 315 , 20-25. https://doi.org/10.1016/j.aquaculture.2010.07.024

Palm, H. W. (2004). The Trypanorhyncha Diesing, 1863. PKSPL-IPB Press, Bogor, $\mathrm{x}+710$ pp. https://www.worldcat.org/title/trypanorhynchadiesing-1863/oclc/224111120

Petter, A. J., \& Sey, O. (1997). Nematode parasites of marine fishes from Kuwait, with a description of Cucullanus trachinoti n. sp. from Trachinotus blochi. Zoosystema, 19, 35-59. https://sciencepress.mnhn.fr/sites/default/files/article s/pdf/z1997n1a4.pdf

Smales, L. R. (2014). Micracanthorhynchina and Serrasentis (Acanthocephala: Rhadinorhynchidae) from Australian fishes, with the description of a new species. Transactions of the Royal Society of South Australia, $\quad$ 138, 92-97. https://doi.org/10.1080/03721426.2014.10887192

Smales, L. R. (2015). Acanthocephala. 317-336. In: Schmidt-Rhaesa, A. (Ed.) Handbook of Zoology: 
Mizher \& Ali / Basrah J. Agric. Sci., 34(2): 133-146, 2021

Gastrotricha, Cycloneuralia and Gnathifera. Volume

3. Gastrotricha and Gnathifera. De Gruyter, Berlin: 354pp.

Tavakol, S., Amin, O. M., Luus-Powell, W. J., \& Halajian, A. (2015). The acanthocephalan fauna of Iran, a check list. Zootaxa, 4033, 237-258. https://doi.org/10.11646/zootaxa.4033.2.3

Van der Laan, R., Fricke, R., \& Eschmeyer, W. N. (Editors.) (2021). ESCHMEYER'S CATALOG OF FISHES: CLASSIFICATION. (http://www.calacademy.org/scientists/catalog-of- fishes-classification/). Electronic version accessed $1^{\text {st }}$ February 2021.

Verweyen, L., Klimpel, S., \& Palm, H. W. (2011). Molecular phylogeny of the Acanthocephala (class Palaeacanthocephala) with a paraphyletic assemblage of the orders Polymorphida and Echinorhynchida. PLoS One, 6, e28285. https://doi.org/10.1371/journal.pone.0028285

WoRMS (2021). Iheringascaris Pereira, 1935. Accessed at:https://www.marinespecies.org/aphia.php?p=taxde tails\&id=731850 on 2021-02-27

\section{Rachycentron canadum (L.) التسجيل الأول لإثنين من الديدان الطفيلية في أسماك السكن من المياه البحرية الإقليمية للعراق (Carangiformes: Rachycentridae)

\author{
جواد عبدالكاظم مزهر و أثير حسين علي \\ قسم الاسماك والثروة البحرية، كلية الزراعة، جامعة البصرة، العراق
}

المستخلص: جمعت 14 عينة من أسماك السكن Rachycentron canadum (L.) من المياه البحرية العراقية خلال الفترة من

شهر تشرين الأول 2019 ولغاية أيار 2020. عزل من القناة الهضمية لهذه الأسماك نوعين من الديدان الطفيلية: نوع من الديدان الخيطية ونوع من الديدان شوكية الرأس، الطور البالغ للدودة للخيطية Iheringascaris inquires (Linton, 1901) Deardorff \& Overstreet, 1980

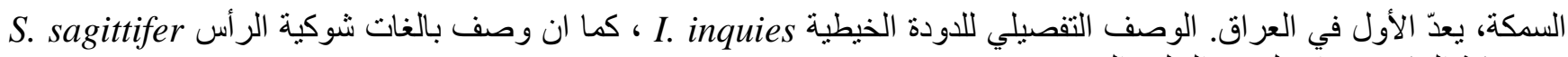
من سمكة السكن يعد الاول من الخليج العربي. كلمات مفتاحية: أسماك بحرية، ديدان خيطية، Iheringascaris inquies، شوكية الرأس، Serrasentis sagittifer، العراق. 